\title{
https://doi.org/10.46813/2021-136-191 \\ RESEARCH ON THE PROPERTIES OF SORBENTS AND DECONTAMINANTS IN THE PROCESSES WITH SMALL ISOTOPE EFFECTS
}

\author{
V.V. Levenets, A.Yu. Lonin, O.P. Omelnik, A.O. Shchur \\ National Science Center “Kharkov Institute of Physics and Technology”, Kharkiv, Ukraine \\ E-mail: levenets@kipt.kharkov.ua
}

\begin{abstract}
The low values of isotope effects in the sorption/decontamination processes make it possible to investigate the properties of the sorbing and decontaminating agents with the use of stable isotope simulators. In the work presented here the element content was determined from the characteristic X-ray emission induced by the proton beam (PIXE), by gamma-ray emission from the radioactive source, and by emission from the X-ray tube. Based on the results of efficiency determination for different kinds of sorbents and decontaminants, recommendations have been given for the choice of materials having the wanted performance characteristics.
\end{abstract}

PACS: 07.77.Gx

High requirements placed upon the ecological safety and the personnel safety of nuclear power facilities cause the development of new materials and refining of the existing ones, which are used for trapping and decontamination of ${ }^{235} \mathrm{U}$ fission products such as ${ }^{131} \mathrm{I}$, ${ }^{137} \mathrm{Cs},{ }^{90} \mathrm{Sr},{ }^{60} \mathrm{Co}$. For capture of ${ }^{131} \mathrm{I}$ and its compounds in air purification filters, of possible use is the application of both impregnated and unnimpregnated carbon of the grades "skt-3", "Electrode-D", "DGF-2", etc. [1 - 3]. For removal of the ${ }^{137} \mathrm{Cs},{ }^{90} \mathrm{Sr},{ }^{60} \mathrm{Co}$ isotopes from liquid radioactive wastes, the most popular practice lies in application of ion-exchange sorbents, e.g., natural and synthetic zeolites [4 - 7]. These zeolites represent a complex aluminum-silicate structure, which is characterized by a combined sorption mechanism $[8,9]$. To clean the equipment of ${ }^{137} \mathrm{Cs},{ }^{90} \mathrm{Sr},{ }^{60} \mathrm{Co}$ contaminants, use can be made of the detergents comprising complexing agents, viz., alginates or pectins $[10,11]$.

The aim of the present work has been to investigate the properties of sorbing and decontaminating agents in order that the materials with higher decontamination/cleanup factor values could be created.

\section{ISOTOPE EFFECTS}

When performing the studies of sorption processes by the use of nuclear physics research methods, it is of importance to estimate the values of isotope effects. These values are determined by differences in the nuclear masses of certain isotopes and are responsible for the distinctions between such properties of isotope compounds as the density, viscosity, diffusivity, heat capacity, thermal conduction, heat of evaporation, melting heat, boiling/fusion temperatures, etc. The isotope effect value decreases with a decrease in the relative difference between the atomic weights of the isotopes. For the studied elements (cobalt, strontium, cesium, iodine), the relative difference in the atomic weights of isotopes (stable and with a half-life of more than $1 \mathrm{~h}$ ) is a few percent. The values of kinetic and thermodynamic isotope effects for these elements have similar values $[12,13]$. A major part of theoretical and experimental investigations into isotope effects was dedicated to the elements of the first three periods of the Periodic Table of the Elements. However, the number of these investi- gations is substantially less for the elements in the middle of the periodic table. In addition to theoretical and experimental laboratory studies of isotope effects [14 $20]$, the results of these effects in the surrounding world are also studied over a period from several years (for example, in the biosphere) to millions and billions of years (the geological environment of the Earth and space objects) [21 - 25]. These great time ranges, which make it possible to detect and register the isotope effects, are required because of their extremely small values. The absorption of iodine and its compounds in the types of unnimpregnated carbon occurs mainly due to the surface absorption process, whereas in the potassium iodide-impregnated kinds of carbon the processes of radioactive iodine absorption are supplemented with the isotope exchange. In the case of zeolites, the compounds of cobalt, strontium, and cesium are absorbed due to chemisorption and ion exchange, while in cleaning means the process of absorption goes owing to complex formation with alginates and pectins. With application of carbon air filters, zeolite and detergent-based liquid filters, the interaction time of the absorbent/detergent agents with the substance under decontamination is sufficiently small for the isotope effects to manifest themselves.

To determine the content of the elements under study in the materials, various physical and nuclear physics methods are of considerable current use [26 27]. Among them, preference is given to the methods based on detection of characteristic X-ray emission (CXE) that can be excited on using accelerated charged particles, radioactive source emission, X-ray tube emission. Unlike the neutron activation analysis, or the analysis based on nuclear reaction radiation, the detected Xray emission is essentially independent of the isotope of the element. For example, it has been demonstrated in ref. [28] that the experimentally measured relative value of the isotopic shift in the energy of the K-series emission from $\mathrm{Sn}, \mathrm{Hf}, \mathrm{W}, \mathrm{Hg}, \mathrm{Pb}, \mathrm{U}$ and some lanthanides amounted only to a few ppm. The analysis of theoretical descriptions and empirical data [29 - 33] in order to estimate the isotopic shift of photon/ion ionization crosssections (and also, the CXE yield) for $\mathrm{K}$ - and L-shells gives much the same order of magnitude. 
Thus, the investigations aimed at developing sorbing and cleaning materials with improved decontamination properties have proved that the elemental analysis results for iodine, cobalt, strontium and cesium and the data determined by the X-ray emission detection method are independent of the isotopic composition of the elements. Hence, the investigations of this type permit the usage of stable isotopes instead of radioactive ana$\operatorname{logs}$ for the corresponding elements.

\section{EQUIPMENT AND MATERIALS}

The analysis of accelerated proton-excited elements was carried out with the use of the NSC KIPT analytical nuclear-physical complex "SOKOL". The main characteristics of the accelerator and its output devices have been described in ref. [34]. Measurements were performed at the output device of channel 1 located on the left at an angle of 45 degrees to the ion beam direction (Fig. 1).

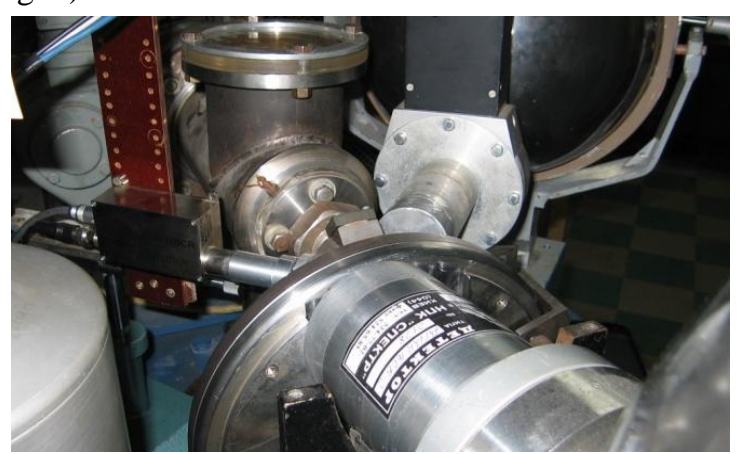

Fig. 1. Channel 1 output of the "SOKOL" complex

The output device includes a vacuum chamber, soft and hard X-ray detection units with $\mathrm{Si}(\mathrm{PiN})$ and highpurity germanium crystals as the base. The radiation is extracted from the chamber through vacuum-tight beryllium windows.

To conduct $\mathrm{X}$-ray radiometric measurements, we have designed and manufactured the measuring module of the "SKIF" test bench [35]. Its parameters were optimized so as to determine the iodine content in a lightweight $10 \mathrm{~cm}^{3}$ matrix, though the module can be also applied for determining the content of elements having atomic numbers ranging from 48 to 56 , which are comprised in such objects as carbon, plant ashes, etc. The external view of the module without the detection unit is shown in Fig. 2.

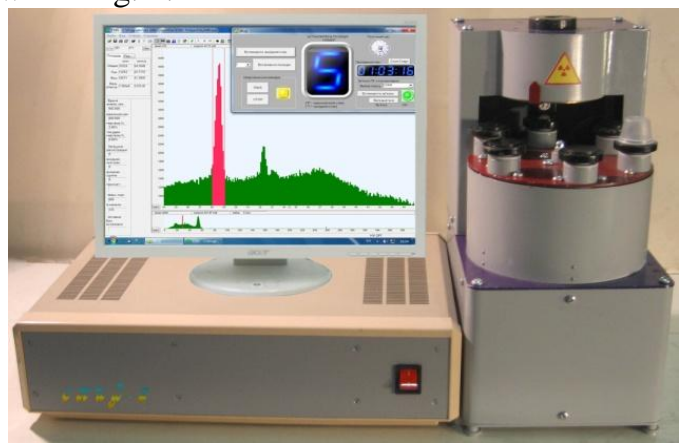

Fig. 2. External view of the "SKIF" measuring module (without the detection unit)

The X-ray fluorescence in the material under study is induced by $59.54 \mathrm{keV}$ radiation from the $3.9 \mathrm{GBq}$ radioactive source ${ }^{241} \mathrm{Am}$ (simultaneous arrangement of up to three similar sources is admissible). The lift-andturn device, serving to deliver the subjects to the irradiation zone, can carry up to 6 containers to be measured, each container being rotated during the measurement. To increase the emission detection efficiency in the energy range from 20 to $30 \mathrm{keV}$, the detection unit with high-purity Ge crystal was used [36].

In the X-ray fluorescence studies, use was made of the small-size NSC KIPT facility "ELEAN", devised for $\mathrm{X}$-ray fluorescent elemental analysis [37]. The background in the channel for detection of X-ray emission coming from the primary radiation of the X-ray tube is suppressed in the facility owing to the effect of partial polarization of the radiation during its reflection from the sample surface. For this purpose, the X-ray optics (Fig. 3) was used with mutually perpendicular arrangement of three axes for sampling the emission from the system: X-ray tube anode - secondary radiator - sample under analysis - X-ray detector. In this case, the detector lies in the plane other than 1-2-3.

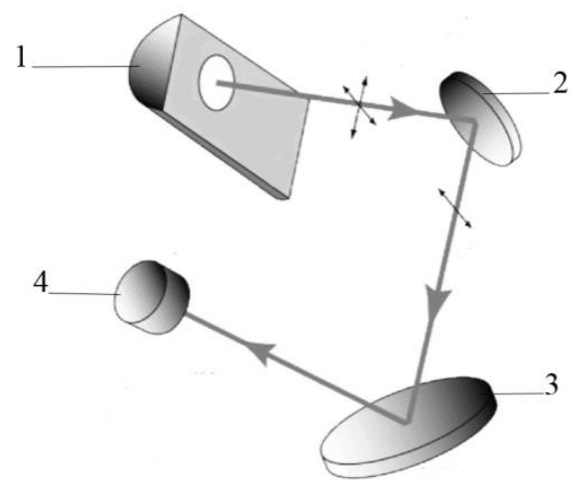

Fig. 3. X-ray optics of the "ELEAN" facility: 1 -X-ray tube; 2 - secondary radiator;

3 - measured sample; 4 -detection unit crystal

For use in the investigations, samples of carbon sorbents "Ehlektrod-D" (Ukraine-manufactured) and "DGF-2" (Germany-manufactured) were subjected to dynamic pumping with the vapors of stable iodine isotope [38]. The external appearance of "Ehlektrod-D" sorbent granules is presented in Fig. 4.

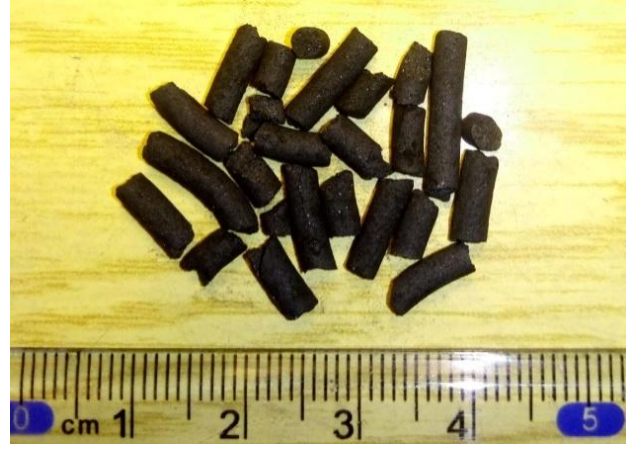

Fig. 4. "Ehlektrod-D” sorbent granules

To determine the iodine content in the carbon by the external standard method, calibration samples were prepared, which comprised sodium iodide in ultrapure carbon with ${ }^{127}$ I mass concentrations ranging from 0.01 to $0.5 \%$.

In the studies into decontamination properties of the developed detergent agent with regard to ${ }^{137} \mathrm{Cs},{ }^{90} \mathrm{Sr}$, and ${ }^{60} \mathrm{Co}$, stable isotope-based simulators of these elements were used. Human hairs were put into nitrate solutions 
of stable cobalt, strontium, cesium isotopes taken separately, and then were dried. After that, a part of each weighed portion was successively washed with the detergent-water solution and was dried again. The weighed portions prepared in this way were pressed to make samples for the measurements in the tableted form.

The sorption properties of zeolites and composite sorbents were investigated under static and dynamic conditions. The solutions under study comprised a mixture of cesium, strontium and cobalt ions. During the experiments, stable compounds of the mentioned elements were used. The targets contained dry residues of the solution on the paper base (filter paper).

\section{RESULTS AND DISCUSSION DETERMINATION OF THE DETERGENT DECONTAMINATION FACTOR}

The detergent decontamination factor was determined from measurements of the stable isotope content with the use of the NPC "SOKOL". The parameters of the accelerated proton beam were chosen to be: $140 \mathrm{keV}$ beam energy, $50 \mathrm{kA}$ average beam current. The analytical lines for cobalt and strontium were provided by the $\mathrm{X}$-ray flyoressence $\mathrm{K}$-series of these elements.

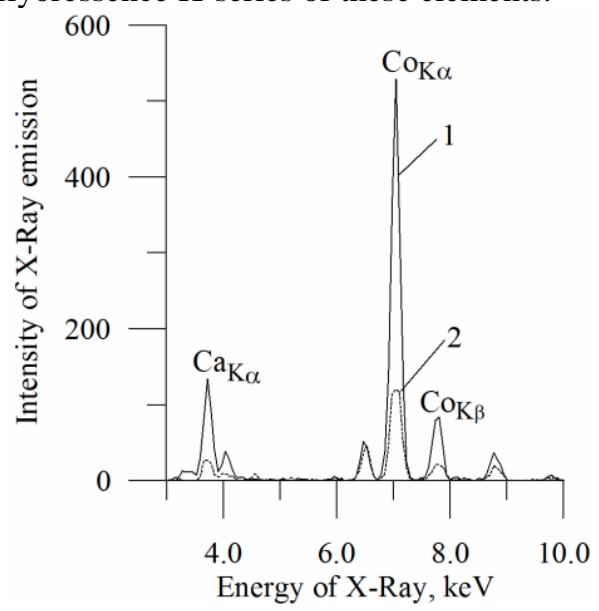

Fig. 5. Spectra from the cobalt-containing human hair before (1) and after (2) detergent decontamination

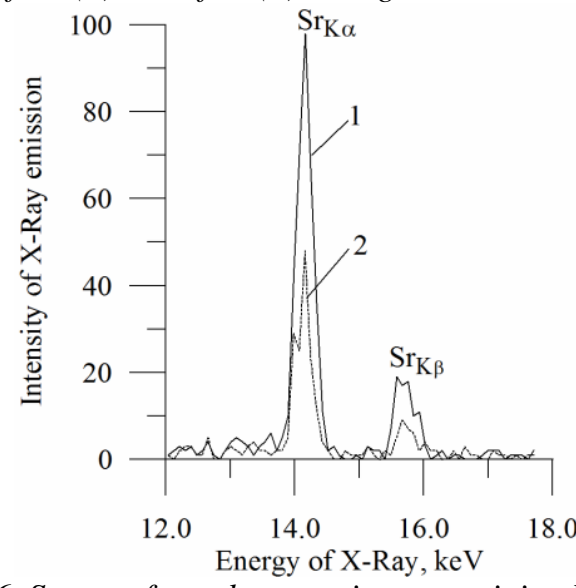

Fig. 6. Spectra from the strontium-containing human hair before (1) and after (2) detergent decontamination

The registration of these lines was performed with the detection units based on $\mathrm{Si}(\mathrm{PiN})$ crystals and highpurity germanium, respectively (Figs. 5 and 6). As regards cesium, its analytical line was taken from the Lseries, which registered by the $\mathrm{Si}(\mathrm{PiN})$ detector (Fig. 7). ISSN 1562-6016. BAHT. 2021. №6(136)

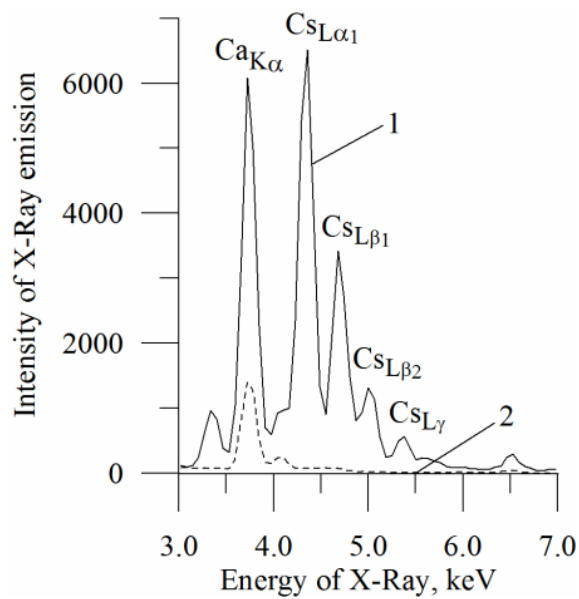

Fig. 7. Spectra from the cesium-containing human hair before (1) and after (2) detergent decontamination

The mathematical processing of the spectrometric information was carried out using the IAEA WinQXAS program. The spectrum processing data were used to determine the decontamination factor. It was calculated as a ratio of the analytical peak areas of the elements under study in the samples before and after treatment with the detergent. The resulting data are listed in the Table.

Detergent decontamination factors for cesium, strontium and cobalt

\begin{tabular}{|c|c|}
\hline Elements & Decontamination factor \\
\hline $\mathrm{Cs}$ & 574.0 \\
\hline $\mathrm{Sr}$ & 3.1 \\
\hline $\mathrm{Co}$ & 3.6 \\
\hline
\end{tabular}

\section{SORPTION PROPERTIES OF CARBON SORBENTS}

The sorption properties of carbon sorbents were investigated by the $\mathrm{X}$-ray radiometry method with the use of the measuring module "SKIF" [39]. Based on the spectra of calibration samples, we could determine the parameters of the calibration straight line by the least squares method. The spectra taken from the carbon sorbents "DGF-2" and "Ehlektrod-D" were used to calculate the iodine content distribution in the filter mockup. The spectral region with the K-series of iodine in the carbon sorbent is shown in Fig. 8.

The sorption properties of the adsorbing agent were estimated by its sorption capacity index $\alpha, \mathrm{s}^{-1}$, which was calculated as $\alpha=\ln \left(\mathrm{C}_{\text {in }} / \mathrm{C}_{\text {out }}\right) / \tau$, where $\tau$ is the time taken by the to pass in through the adsorption layer (conditioned contact time), $\mathrm{s} ; \mathrm{C}_{\mathrm{in}}$ and $\mathrm{C}_{\text {out }}$ are, respectively, the iodine mass concentrations in the initial and final layers of carbon in the filter mockup, $\%$ [40, 41].

According to the IAEA guidelines, as well as the USA and European standards [42, 43], the minimum value of the ratio of the iodine content of air at the inlet of the model adsorber to the iodine value at the outlet of the model adsorber must be no less than 100: $\mathrm{C}_{\mathrm{in}} / \mathrm{C}_{\text {out }}>100$ (or 4.605 in logarithmic representation: $\left.\ln \left(\mathrm{C}_{\text {in }} / \mathrm{C}_{\text {out }}\right)>4.605\right)$. 


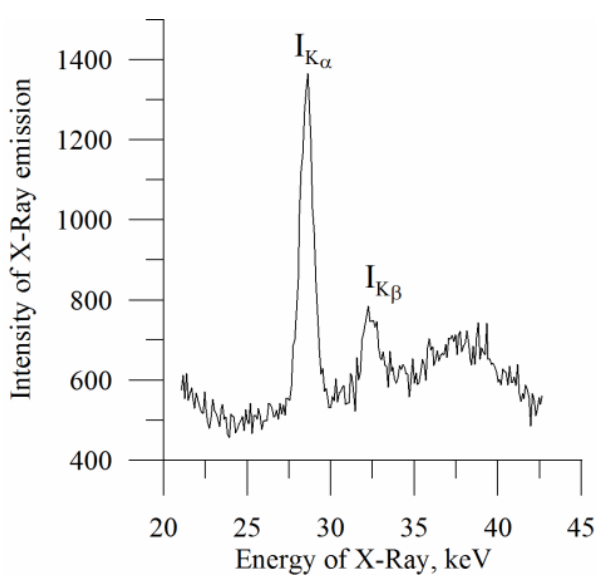

Fig. 8. Spectral region of the carbon sorbent

"Ehlektrod-D" under investigation

The processing of the obtained spectrometric information has demonstrated that the logarithm of the ratio of the output iodine concentration to the iodine concentration in the layer at the input of the model filter amounts to 13.29 and 6.99 for "DGF-2" and "EhlektrodD" sorbents, respectively.

\section{SORPTION PROPERTIES OF ZEOLITES}

The content of $\mathrm{Co}, \mathrm{Cr}$, Cs in the prepared samples subjected to decontamination of solutions with zeolites was determined by means of the "ELEAN" facility. The anode voltage of the X-ray tube was set to be $50 \mathrm{kV}$, and the anode current was equal to $20 \mathrm{~mA}$. Germanium was used as a secondary radiator. The content of Co and $\mathrm{Sr}$ was determined using X-ray emission the K-series, while the Cs content was found using the X-ray emission L-series. Fig. 9 shows the spectral region for the strontium-containing test sample after zeolite-based sorption.

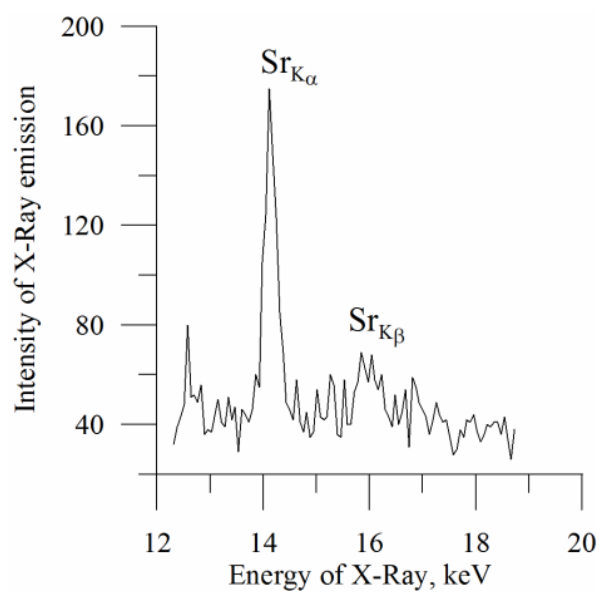

Fig. 9. Spectral region for the strontium

nitrate-containing sample subjected to sorption

For quantitative estimation of the sorption properties of zeolites we have used the sorption coefficient $\left(\mathrm{K}_{\mathrm{s}} \%\right)$, which was calculated by:

$$
K_{s}=\frac{\left(C_{0}-C_{p}\right) \cdot 100 \%}{C_{0}},
$$

where $\mathrm{C}_{\text {init }}$ and $\mathrm{C}_{\mathrm{eq}}$ are, respectively, the initial and equilibrium concentrations of the solution, mole/ $\mathrm{dm}^{3}$.

The obtained results bear witness to high sorption properties of natural zeolite-clinoptilolite in relation to cesium. As regards cobalt and strontium, clinoptilolite shows some deterioration of its sorption properties. On the contrary, the synthetic zeolites exhibit higher sorption properties with relation to cobalt and strontium [44].

\section{CONCLUSIONS}

The present investigations have demonstrated that the isotopic composition of contaminants has little or no effect on the determination of decontamination/cleanup factors for materials of different grades used in atomic energy industry.

A high value of the cleanup factor of the developed detergent agent has been found with respect to cesium.

It has been established that the decontamination factors of the carbon sorbents intended for air purification filters of nuclear power plants meet the IAEA requirements.

The analytical studies have confirmed the data that the natural zeolite (clinoptilolite) exhibits a high selectivity to cesium, but shows a substantially lower efficiency in the cases of cobalt and strontium. The fact that high sorption properties with respect to the ions of these elements are shown by synthetic zeolites, opens the prospect for the combined use of both natural and synthetic zeolites.

\section{REFERENCES}

1. J.G. Wilhelm. Iodine Filters in Nuclear Installations. Commission of the European Communities, V/2110/83, 1982.

2. Russian National Standard. Iodine sorbents for nuclear power plants. The method of sorptivity index determination. Moscow, 2011, $30 \mathrm{p}$.

3. C.I. Lavrov, V.V. Levenets, V.I. Sokolenko. Certification of carbon sorbents for NPP vent systems. Kharkiv: "Zebra", 2019, 274 p.

4. V.V. Levenets, A.Yu. Lonin, O.P. Omelnik, A.O. Shchur. PIXE in the studies of stable cesium sorption from water solutions // X-Ray Spectrometry. 2015, № 44 (6), p. 447-450. DOI 10.1002/xrs.2626.

5. A.Yu. Lonin, V.V. Levenets, I.M. Neklyudov, A.O. Shchur. The usage of zeolites for dynamic sorption of cesium from waste waters of nuclear power plants // J. Radioanal. Nucl. Chem. 2015, v. 303, p. 831-836.

6. A.Yu. Lonin, V.V. Levenets, O.P. Omelnik, A.O. Shchur. Comparison of the sorption properties of natural and synthetic zeolites for the purification of aqueous solutions from cobalt: sorption of the cobalt from aqueous solutions in dynamic conditions and the quantitative determination of cobalt by the PIXE method // J. Radioanal. Nucl. Chem. 2018, v. 315(2), p. 163-169. DOI 10.1007/s10967-0175676-1.

7. V.V. Levenets, A.Yu. Lonin, O.P. Omelnik, A.O. Shchur. Comparison the sorption properties of clinoptilolite and synthetic zeolite during sorption strontium from the water solutions in static conditions: sorption and quantitative determination of strontium by the method PIXE // Journal of Environmental Chemical Engineering. 2016, № 4, p. 3961-3966. 
8. D. Breck. Zeolite molecular sieves. Moscow: "Mir", 1976, 606 p.

9. N.A. Shul'ga, I.D. Sokolova. Liquid waste processing at NPP // Atomnaya tekhnika za rubezhom. 2008, № 9, p. 3-19 (in Russian).

10. Patent № 31190 Ukraine. Decontamination shampoo (In Ukrainian) // G.V. Gordyuk, V.M. Ivanov, M.V. Nekhoroshev; applicant and proprietor of patent: South Seas Biology Institute. Bulletin № 5, 2001.

11. Utility model patent № 26693 Ukraine. Universal Decontamination shampoo // A.A. Shokur; applicant and proprietor of patent: A.A. Shokur. Bulletin № $16,2007$.

12. A.I. Brodskiy. Chemistry of isotopes. Revised and enlarged edition./ AS USSR Press. Moscow, 1957, $596 \mathrm{p}$.

13. Ya.S. Kayukov, O.V. Kayukova, A.V. Eremkin, et al. Organic chemistry. Theoretical foundations Educational guidance. / Cheboksary Univ. Press, 2007, $155 \mathrm{p}$.

14. P.W. Huppe and F. Faupe Isotope effect of Co diffusion in amorphous $\mathrm{Co}_{76.7} \mathrm{Fe}_{2} \mathrm{Nb}_{14,3} \mathrm{~B}_{7} / /$ Physical Review B. July 1992-I, v. 46, № 1, p. 120-125.

15. Haimanti Chakrabarti. Strong evidence of an isotope effect in the diffusion of a $\mathrm{NaCl}$ and $\mathrm{CsCl}$ solution // Physical review B. May 1995-II, v. 51, № 18, p. 12809-12812.

16. Meheut, Merlin; Ibanez-Mejia, Mauricio; Tissot, L.H. Francois. Drivers of zirconium isotope fractionation in Zr-bearing phases and melts: The roles of vibrational, nuclear field shift and diffusive effects // Geochimica et cosmochimica acta. Jan. 2021, v. 29, p. 217-234.

17. Faina Gelman, Agnieszka Dybala-Defratyka. Bromine isotope effects: Predictions and measurements. // Chemosphere. May 2020, v. 246, № Publ. 125746.

18. Van Groos, Paul G. Koster; Esser, Bradley K.; Williams, Ross W., et al. Isotope Effect of Mercury Diffusion in Air // Environmental science and technology. Jan. 2014, v. 45, № 1, p. 227-233.

19. Fukuda, Yuji; Zhang, Yong-Hong; Nomura, Masao, et al. Strontium Isotope Effects Observed in Liquid Chromatography with Crown Ether Resins // Journal of Nuclear Science and Technology. 2010, v. 47, № 2, p. 176-183.

20. P.G. Kervalishvili. On isotope effects in condensed media // Bulletin of the Russian Academy of Natural Sciences. 2014, issue. 1, p. 3-10.

21. Tobias R.A. Denk, Joachim Mohn; Charlotte Decock, et al. The nitrogen cycle: A review of isotope effects and isotope modeling approaches // Soil biology and biochemistry. 2017, v. 105, p. 121-137.

22. Y. Xia, E.S. Kiseeva, J. Wade, et al. The effect of core segregation on the $\mathrm{Cu}$ and $\mathrm{Zn}$ isotope composition of the silicate Moon // Geochemical perspectives letters. 2019, v. 12, p. 12-17.

23. Yang, Sha; Liu, Yun. Nuclear field shift effects on stable isotope fractionation: a review // Acta geochimica. 2016, v. 35, issue. 3, p. 227-239. DOI 10.1007/s11631-016-0109-3.

24. Weissman, Benjamin P.; Li, Nan-Sheng; York, Darrin, et al. Heavy atom labeled nucleotides for measurement of kinetic isotope effects // Biochimica et biophysica acta-proteins and proteomics. 2015, v. 1854, issue 11, p. 1737-1745. DOI: 10.1016/j.bbapap.2015.03.007.

25. Van Orman, James A.; Krawczynski, Michael J. Theoretical constraints on the isotope effect for diffusion in minerals // Geochimica et cosmochimica acta. 2015 , v. 164 , p. $365-381$.

26. N.A. Azarenkov, V.G. Kirichenko, V.V. Levenets, I.M. Neklyudov. Nuclear-physical analysis methods in materials science: educational guidance. Харьков: V.N. Karazin State Univ. Press, 2013, $300 \mathrm{p}$.

27. E.Yu. Boyarko, Yu.Yu. Kryuchkov, I.P. Chernov. Nuclear methods of condensed media analysis: educational aid. Tomsk: Tomsk Polytechnical Univ. Press, 2008, 303 p.

28. S.K. Bhattacherjee, F. Boehm, P.L. Lee. Nuclear Charge Radii from Atomic K X Rays // Phys. Rev. 1969, v. 188, issue. 4, p. 1919-1929.

29. A.M. Shaimardanov, V.N. Kaurov, E.A. Petrova. Semiclassical approach with asymptotic development of the Heitler formula for atom photoionization // Proceedings of the Kazan' University. Series "Physico-mathematical Sciences". 2020, v. 162, issue. 2 , p. 211-222. DOI: 10.26907/25417746.2020.2.211-222.

30. M.Ya. Amus'ya, V.K. Ivanov. Intershell interaction in atoms // Uspekhi Fiz. Nauk. 1987, v. 152, issue. 2, p. 185-230 (in Russian).

31. D.D. Cohen and M.K. Harrigan. L-shell ionization cross-sections for protons and helium ions calculated in the ECPSSR theory // At. Data and Nucl. Dat. Tables. 1985, v. 33, p. 255-275.

32. S.A.E. Johansson, T.B. Johansson. Analytical application of particle-induced X-ray emission // Nucl. Instr. and Meth. 1976, v. 137, p. 473-516.

33. A.P. Omel'nik, V.V. Levenets, A.A. Shchur. Analytical representation of cross-sections for accelerated proton-induced ionization of lanthanide K-shells // Fizicheskaya inzheneriya poverkhnosti. 2012, v. 10, № 2, p. 211-216 (in Russian).

34. V.N. Bondarenko, L.S. Glazunov, A.V. Goncharov, et al. Analytical nuclear physical complex "Sokol" (NSC KIPT) // Book of Abstracts "International Conference Current Problems in Nuclear Physics and Atomic Energy». Kyiv, Ukraine, May 29 - June 03, 2006, p. 852-857.

35. V.V. Levenets, V.I. Sokolenko, E.I. Vinokurov, O.Yu. Lonin, O.P. Omel'nyk, R.M. Sibileva, A.O. Shchur. Inspection stand of carbon-sorbent iodine filters (SKIF) for NPP ventilation systems // Purpose-oriented package program of the Ukrainian National Academy of Sciences "Reliability and durability of materials, structures, facilities and constructions". Collection of scientific articles based on the findings in 2016-2020. Paton Institute of Electric Welding. NASU, Kyiv: 2020, p. 308-315.

36. O.P. Omelnyk, V.V. Levenets, A.Yu. Lonin, A.O. Shchur. Spectrometric Characteristics of Various Detectors for X-Ray Determination of Iodine from K-Series Line Emission using ${ }^{241} \mathrm{Am}$ as the Source // Methods and objects of chemical analysis. 2015, v. 10, № 3, p. 128-134. 
37. A.P. Omelnik, V.V. Levenets, V.A. Zaporozhchenko, A.A. Shchur, I.V. Shevchenko. The MSC KIPT X-ray fluorescence analysis facility "ELEAN": arrangement, metrological characteristics // $3^{\text {rd }}$ International Conference "High-purity materials: production, applications, properties”. 2015, 15-18 Sept., p. 35. Reports. Kharkov.

38. The measurement procedure for determining the carbon sorbent decontamination factor by the nuclear-physics analytical method. Local standard. MVU 12-227:2014 NSC KIPT, Kharkiv, 2018, 30 p.

39. O.P. Omelnyk, V.V. Levenets, A.Yu. Lonin, A.O. Shchur. Comparison of methods for determination of iodine in carbon, based on the detection of the characteristic x-ray radiation // Problems of Atomic Science and Technology. Series "Physics of Radiation Effect and Radiation Materials Science”. 2015, № 5, p. 145-151.

40. V.V. Levenets, V.I. Sokolenko, E.I. Vinokurov, A.Yu. Lonin, A.P. Omelnik, R.M. Sibileva,
A.A. Shchur. Determination of the coefficient of iodine absorption carbon materials adsorber ventilation NPP using stable isotopes // Problems of Atomic Science and Technology. Series "Vacuum, Pure Materials, Superconductors”. 2016, № 1, p. 56-60.

41. V.V. Levenets, A.Yu. Lonin, A.P. Omelnik, V.I. Sokolenko, A.O. Shchur. Comparative assessment of the sorption properties of carbon filters used in the ventilation system of NPP, using ${ }^{131} \mathrm{I}$ and ${ }^{127} \mathrm{I} / /$ Nuclear Physics and Atomic Energy. 2017, v. 18, № 1, p. 37-42.

42. Testing and Monitoring of Off-Gas Cleaning Systems at Nuclear Facilities: Technical Report. Series № 247, IAEA, Vienna, 1984.

43. D3803-91(2009). Standard Test Method for Nuclear Grade Activated Carbon // ASTM International. 2009, 18 p.

44. Useful model patent № 145295. Sorbent for radionuclides absorption. 25.11.2020.

Article received 28.09.2021

\section{ИЗУЧЕНИЕ СВОЙСТВ СОРБЕНТОВ И ДЕЗАКТИВИРУЮЩИХ СРЕДСТВ В ПРОЦЕССЕ С МАЛЫМИ ВЕЛИЧИНАМИ ИЗОТОПНЫХ ЭФФЕКТОВ}

\section{В.В. Левенец, А.Ю. Лонин, А.П. Омельник, А.А. Щур}

Благодаря малым значениям величин изотопных эффектов у процессах сорбции и дезактивации возможно изучение свойств исследуемых нами сорбентов и дезактивирующих средств по использованию имитаторов со стабильными изотопами. В представленных исследованиях элементное содержание определялось с использованием характеристического рентгеновского излучения, возбуждаемого пучком протонов, гаммаизлучением от радиоактивного источника, излучением от рентгеновской трубки. По результатам определения эффективности различных типов сорбентов и дезактивирующих средств даны рекомендации по выбору материалов с необходимыми характеристиками.

\section{ВИВЧЕННЯ ВЛАСТИВОСТЕЙ СОРБЕНТІВ І ДЕЗАКТИВУЮЧИХ ЗАСОБІВ У ПРОЦЕСАХ 3 МАЛИМИ ВЕЛИЧИНАМИ ІЗОТОПНИХ ЕФЕКТІВ}

\section{В.В. Левенець, О.Ю. Лонін, О.П. Омельник, А.О. Щур}

Завдяки малим значенням величин ізотопних ефектів у процесах сорбції та дезактивації можливо вивчення властивостей досліджуваних нами сорбентів і дезактивуючих засобів з використання імітаторів зі стабільними ізотопами. У представлених дослідженнях елементний вміст визначався з використанням характеристичного рентгенівського випромінювання, що порушувався пучком протонів, гамма-випромінюванням від радіоактивного джерела, випромінюванням від рентгенівської трубки. За результатами визначення ефективності різних типів сорбентів і дезактивуючих засобів надано рекомендації щодо вибору матеріалів з необхідними характеристиками. 